of Welsh antiquities peculiarly fitted him, and of the advisory board on Ancient Monuments in England.

As an archæologist, Bosanquet had a high reputation among the expert, but neither his achievement nor its qualities was such as to lend itself to building up wide popular recognition. He was one of the group who, following closely in the footsteps of Sir Arthur Evans, at the turn of the century and in the years immediately following placed British archæology in the field in a commanding position in international scholarship; and Bosanquet was one of those who helped to extend that meticulous care in excavation, characteristic of field work in the Mediterranean, to the study of Romano-British sites. As director of the British School at Athens he worked in Crete, where he was responsible for the excavation of the archæologically valuable site of Palækastro, at Phylakopi and in Laconia, where he initiated the important excavation of the temple of Artemis Orthia. He was the author of "Borcovicium" (1904) and part author of "Phylakopi" (1904), but the principal part of his contribution to archæological literature appears in the Annual of the British School, the Journal of Hellenic Studies and other periodicals. His work was accurate and precise, and informed with wide knowledge. It showed all the polished definition to be expected of a finished scholar.

\section{Prof. E. Poulsson}

WITH the death on March 19, at the age of seventyseven years, of Prof. E. Poulsson, Norway has lost one of her foremost scientific workers. He was chiefly known on account of his work in connexion with the fat-soluble vitamins as they are found in cod liver oil. In innumerable papers he has shown that the female organism in the sexually mature years has a greater vitamin reserve than the male. Similarly, he has proved that the chondropteryginous fishes - in contradistinction to the osseous-are only endowed with negligible quantities of vitamin $\mathrm{D}, \mathrm{a}$ substance which they manifestly do not require as their framework is only to a very limited extent composed of lime compounds.

Prof. Poulsson was deeply interested in the importance of cod liver vitamins to the growing organism. He showed in several papers the part played by these vitamins in relation to the unborn individual and in habitual abortion, and he did much to extend our knowledge of the medicinal importance of cod liver oil. One of the most important of Prof. Poulsson's contributions to the cause of vitamin research is undoubtedly his well-known method for the quantitative determination of vitamin $D$. By this method vitamin $\mathrm{D}$ was determined in Oslo-units and these were in use in many countries until the international units were introduced. As Norway's representative, Prof. Poulsson was a member of the League of Nations Vitamin Standardisation Committee.

In the sphere of pharmacology Prof. Poulsson was particularly well known. His textbook on this subject is used in many parts of the world in English, Spanish and German translations, and ten editions have been published. The book successfully combines theoretical thoroughness with practical insight. Written in an easy style, it is an invaluable aid for the ordinary practitioner.

Prof. Poulsson was born in 1858. He became a doctor of medicine in 1892, studied chemistry under Fresenius at Wiesbaden and pharmacology under Schmiedeberg at Strasbourg. He was professor of pharmacology at the University of Oslo in 1895-1928. As professor emeritus from 1928 until his death, he was director of the State Vitamin Institute. His charm and directness of manner gained him many friends both at home and abroad.

OtTAR Rygh.

THE death of the eminent American medical historian Lieut.-Colonel Fielding Hudson Garrison at the age of seventy-four years took place on April 18 in the Johns Hopkins Hospital. He was the author of an introduction to the "History of Medicine" (fourth edition, 1929) and numerous articles on the history of medicine, as well as co-editor for some years of the Index Medicus, Quarterly Cumulative Index, and Annals of Medical History, consulting librarian to the New York Academy of Medicine and librarian to the Welch Medical Library at Johns Hopkins University.

We regret to announce the death on April 9 of Dr. Edouard Antoine Jeanselme at the age of seventy-four years; he was formerly professor of diseases of the skin and syphilis in the Paris faculty of medicine, author of an authoritative work on leprosy (1934) and editor of a treatise on syphilis in several volumes in course of publication.

WE regrot to announce the following deaths:

Prof. J. E. Guthrie, professor of zoology in Iowa State College, on April 16, aged sixty-three years.

Prof. T. C. Hopkins, formerly professor of geology in Syracuse University, known for his work on building stones, clays and iron ores, on April 3, aged seventy-three years.

Prof. George E. Johnson, professor of zoology in the Kansas State College, an authority on the physiology of hibernation, on March 18, aged forty-five years.

Prof. Wilhelm Kolle, director of the State Institute for Experimental Therapy and of the Georg. Speyer-Haus Chemo-Therapeutical Institute, Frankfurt, on May 10, aged sixty-four years.

Prof. J. L. R. Morgan, professor of physical chemistry in Columbia University, on April 12, aged sixty-two years.

Prof. E. B. Skinner, emeritus professor of mathematics in the University of Wisconsin, on April 3, aged seventy-one years.

Dr. H. H. Thomas, F.R.S., petrographer to H.M. Geological Survey, on May 12, aged fifty-nine years.

Sir James Walker, F.R.S., emeritus professor of chemistry in the University of Edinburgh, on May 6, aged seventy-two years. 